\title{
NEW RECORDS OF RARE MARINE FISHES FROM THE GULF OF MANNAR, INDIA
}

\author{
Vinay P. PADATE, Ravi RODRIGUES, and Chandrashekher U. RIVONKER* \\ Department of Marine Sciences, Goa University, Taleigao Plateau, Goa 403206, India
}

Padate V.P., Rodrigues R., Rivonker C.U. 2014. New records of rare marine fishes from the Gulf of Mannar, India. Acta Ichthyol. Piscat. 44 (3): 241-248.

\begin{abstract}
The Gulf of Mannar is a haven for rare species, which along with their pristine reef habitats are under constant threat from natural phenomena and anthropogenic activities. Therefore, the presently reported study aimed at documenting and inventorying rare benthic epi-faunal taxa from the region. We undertook 23 bottom trawl hauls at depths between 14 and $153 \mathrm{~m}$ in the Gulf of Mannar. Additionally, we collected rare fishes from the Tuticorin fisheries jetty. Our findings revealed that Parapterois heterura (Bleeker, 1856) is a new record for the Indian waters. Additionally, four species namely Ebosia falcata Eschmeyer et Rama-Rao, 1977, Pseudanthias marcia Randall et Hoover, 1993, Apogon queketti Gilchrist, 1903, and Roa jayakari (Norman, 1939) are new records for the east coast of India outside their known geographical range, whereas five other teleosts (Ostichthys acanthorhinus Randall, Shimizu et Yamakawa, 1982, Apogon semiornatus Peters, 1876, Histiopterus typus Temminck et Schlegel, 1844, Macropharyngodon ornatus Randall, 1978, and Scolopsis xenochroa Günther, 1872) are new records for the east coast of India. The present paper supplements the existing knowledge of benthic invertebrate taxa from this region, which is mandatory to understand the role of these species in ecosystem functioning.
\end{abstract}

Keywords: reef fishes, bottom trawl, taxonomy, morphometry, meristic counts

The Gulf of Mannar (10 $500 \mathrm{~km}^{2}$ ) situated between India and Sri Lanka comprises 21 small islands surrounded by fringing coral reefs (Venkataraman et al. 2004). This region is known to be one of the richly endowed in terms of finfish diversity i.e., 538 species (Venkataraman and Wafar 2005). Recent developmental activities including large scale fishing and shipping activities as well as the proposed $83.2 \mathrm{~km}$ long Sethusamudram Shipping Canal Project (Kathal 2005) are potential threats to the pristine marine habitats in the region. However, published literature pertaining to rare marine fishes from the region is scanty (Dorairaj 1998, Venkataramani et al. 2005, Varghese et al. 2011) largely due to inadequate taxonomic expertise. In view of the above, documentation and inventorying of the demersal fauna of the region with particular emphasis on rare species was envisaged. The presently reported study reveals ten new records of teleosts collected from bottom trawl catches operated in the Gulf of Mannar.

The presently reported study area encompasses the trawling grounds in the southern Gulf of Mannar, located off south-eastern coast of India (Fig. 1) down to $150 \mathrm{~m}$ depth. During the reported study period (July 2012 to March 2013), 23 trawling operations with a total effort of $35 \mathrm{~h}$ were undertaken in the study area to assess the diversity and total community structure of demersal fish fauna. Rare specimens encountered in the trawl hauls were picked out and temporarily stored in ice. At the laboratory, a detailed morphological study of the biological specimens was carried out using identification keys provided in FishBase (Froese and Pauly 2013) and other taxonomic literature (Allen 1999, Heemstra and Randall 1999, Poss 1999, Heemstra 2001, Pyle 2001, Russell 2001, Westneat 2001). Classification of higher taxa followed Nelson (2006), that of fish families followed van der Laan et al. (2013), and that of genera and species followed Eschmeyer (2013). Reference voucher samples are deposited at the Marine Biology Laboratory, Department of Marine Sciences, Goa University (GUMSMB).

Abbreviations used in the text are as follows. $\mathrm{A}=$ anal fin; $\mathrm{D}=$ dorsal fin; $\mathrm{D}_{1}=$ first dorsal fin; $\mathrm{D}_{2}=$ second dorsal fin; GR = gill rakers; HL = head length; $L L=$ lateral line scale number; $\mathrm{P}=$ pectoral fin; $\mathrm{SL}=$ standard length; $\mathrm{SnL}=$ snout length; $\mathrm{V}=$ pelvic fin.

\section{HOLOCENTRIDAE Bonaparte, 1833}

Ostichthys Cuvier in Cuvier et Valenciennes, 1829 Ostichthys acanthorhinus Randall, Shimizu et Yamakawa, 1982

Material examined: 3 unsexed specimens, 94.5-95.8 mm SL, Gulf of Mannar, $103 \mathrm{~m}$ depth, demersal trawl, Cat. No. GUMSMB/TTN/TELO-6/01.

\footnotetext{
${ }^{*}$ Correspondence: Prof. Chandrashekher U. Rivonker, Department of Marine Sciences, Goa University, Taleigao Plateau, Goa 403206, India, phone: (+91) 832-6519352, e-mail: (CUR) curivonker@gmail.com, (VPP) vinaypadate@gmail.com, (RR) rrruirod030@gmail.com.
} 
Diagnosis: D XII, 13; A IV, 11; P 17; V I 7; GR 25-26; LL 28-29. Body covered with large ctenoid scales; body depth: 2.08-2.11 in SL; head large, 2.04-2.13 in SL, snout short, 6.19-6.44 in HL; prominent spine at anterior end of each nasal bone; orbit large, its diameter 7.44-7.85 in SL; preopercular edge serrate, with short, stout spine at corner; rear edge of opercle serrate, with prominent spine on dorso-posterior edge; $3 \frac{1}{2}$ scale rows between lateral line and middle of spinous dorsal fin; caudal peduncle slender, caudal fin forked. Body colouration bright red, with golden sheen on sides, fins translucent red (Fig. 2A). Geographical distribution: Gulf of Oman, Kerala (west coast of India), and Indonesia (Randall et al. 1982).

Remarks: Ostichthys acanthorhinus unmistakably differs from its congeners in the presence of a prominent spine at anterior end of each nasal bone. This is a deep water species (down to $336 \mathrm{~m}$ depth) initially described from specimens off Oman and Kerala (Randall et al. 1982). The present observation reveals that this species is a new record for the east coast of India.

\section{SCORPAENIDAE Risso, 1827}

Parapterois Bleeker, 1876

Parapterois heterura (Bleeker, 1856)

Material examined: 2 unsexed specimens, 34.3-61.6 mm SL, Gulf of Mannar, $70 \mathrm{~m}$ depth, demersal trawl, Cat. No. GUMSMB/TTN/TELO-25/15.

Diagnosis: D XIII, 9; A III, 8; P 20; V I 5; GR 17. Body elongate, covered with large ctenoid scales (50 in longitudinal series), its depth 3.15-3.21 in SL; head long, $2.57-2.88(34.69 \%-39.12 \%)$ in SL; snout $3.05-3.17$ $(11.37 \%-12.34 \%)$ in HL; upper margin of orbit distinctly below level of first dorsal spine base; interorbital space scaleless; top of bulge on snout at level of midline of pupil; tip of tentacle on lacrimal posterior spine extending beyond level of posterior margin of maxilla; dorsal fin with deeply incised membrane between spines, pectoral fin extending posterior to anal fin origin, caudal fin long, its median rays longest. Body coloration reddish with seven bands in head region and nine on body, ventral sur- face of body whitish, dorsal, anal and caudal fins reddish with alternating light coloured bands, pectoral fins red with greenish blotches (Fig. 2B).

Geographical distribution: Western Indian Ocean and Western Pacific regions (Motomura 2004).

Remarks: Parapterois heterura is distinguished from its only congener Parapterois macrura (Alcock, 1896) in possessing shorter head and snout, level of upper orbital margin below the base of first dorsal spine, and top of bulge on the snout at level of middle of pupil (Motomura 2004). The percentages of HL and SnL in SL for the specimens examined in this study were concurrent with the prescribed morphometric ratios for $P$. heterura (see Motomura 2004). Parapterois macrura is known from the west coast of India (Motomura 2004), Oman and Somalia (Matsunuma et al. 2013). Motomura (2004) recently reviewed the taxonomic status of these two species and opined that $P$. heterura occurred along south-east coast of Africa, Indonesia, and western Pacific regions. Hence, the presently reported observation of this species is a new record for the Indian waters.

\section{Ebosia Jordan et Starks, 1904}

Ebosia falcata Eschmeyer et Rama-Rao, 1978

Material examined: 3 unsexed specimens, 89.2-99.8 mm SL, Gulf of Mannar, $106 \mathrm{~m}$ depth, demersal trawl, Cat. No. GUMSMB/TTN/TELO-25/14.

Diagnosis: D XIII, 10; A III, 8; P 16-17; V I 5; GR 14. Body elongate, covered with large ctenoid scales; dorsal profile prominently arched above operculum; parietal crest very long; dorsal fin with deeply incised membrane between spines, pectoral fin extending posterior to anal fin origin, caudal fin long, its median rays longest; preopercle with 3 spines; suborbital ridge with more than 10 spinous points. Body coloration reddish with nine blackedged bands including three on head (first two below eye, third posterior to preopercle) and six on body, ventral surface of body whitish, dorsal fin spines reddish with white tips, dorsal rays distally yellow, pectoral fins reddish basally, its lower rays prominently yellow, caudal and anal fins yellow (Fig. 2C).

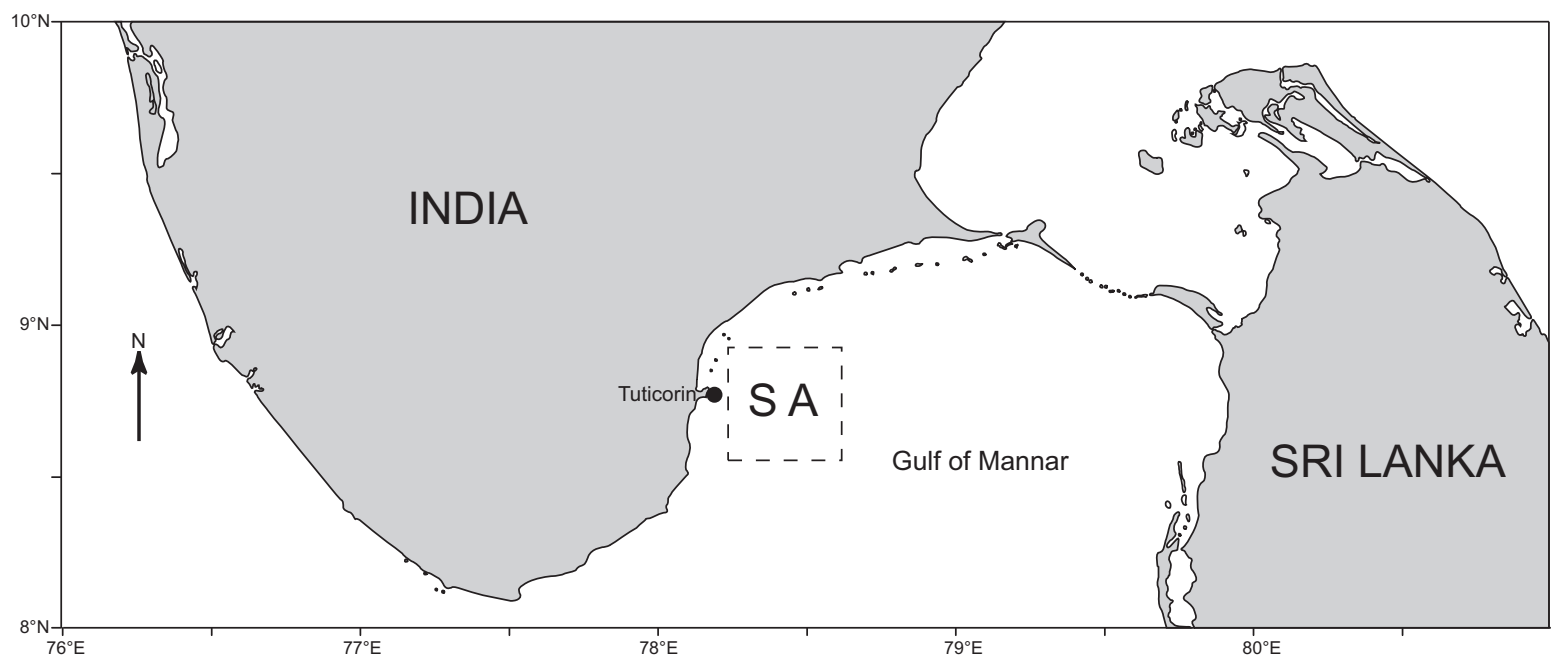

Fig. 1. Map of the study area in the Gulf of Mannar; SA = study area 
Geographical distribution: Somalia and western coast of India (Eschmeyer and Rama-Rao 1977).

Remarks: Ebosia falcata is distinguished from its only congener-Ebosia bleekeri (Döderlein, 1884) in possessing higher number of spines in dorsal fin (VIII in the latter), and a longer parietal crest. Eschmeyer and Rama-Rao (1977) reported this species from the east coast of Africa and west coast of India. However, the present reporting of this species from this locality suggests its range extension to the east coast of India.

SERRANIDAE Swainson, 1839

Pseudanthias Bleeker, 1871

Pseudanthias marcia Randall et Hoover, 1993

Material examined: 1 female specimen (73.3 $\mathrm{mm} \mathrm{SL})$, 1 male specimen $(76.0 \mathrm{~mm} \mathrm{SL})$, trawl by-catch at Tuticorin fisheries harbour, Cat. No. GUMSMB/TTN/TELO-23/04. Diagnosis: D X 16; A III 7; P 20; V I 5; LL 47; total GR 37-38. Body slender, covered with ctenoid scales, its depth 2.84-3.03 in SL; head 3.33-3.35 in SL, snout short, 5.24-5.40 in HL. Male pinkish with light violet streak extending from below orbit to pectoral fin base, golden yellow patch below soft dorsal fin; two parallel lines extending from dorsal fin, terminating at base of caudal fin; uppermost caudal ray terminating in long filament (Fig. 2D). Female with protuberance on snout, bright red coloration on upper portion of body and posterior caudal fin margin, distinct violet streak extending from snout to pectoral fin base, lower and middle portion of body bright yellow, and lacking of filament on upper caudal fin lobe (Fig. 2E).

Geographical distribution: Oman (Randall and Hoover 1993) and Arabian Sea off south-west coast of India (Nair 2008). Remarks: Pseudanthias marcia differs from its congeners in possessing filamentous caudal fin in males, deep concave caudal fin in females and its unique coloration pattern (Nair 2008, Heemstra and Akhilesh 2012). The pectoral fin ray counts in both the observed specimens were 20 as compared to 18 reported previously by Nair (2008), which could be a geographical variation. This species has been reported from Oman and off the southwest coast of India. Hence, the present observation suggests that this species is a new record for the east coast of India, outside its previously reported geographical range.

APOGONIDAE Günther, 1859

Apogon Lacepède, 1801

Apogon queketti Gilchrist, 1903

Material examined: 3 unsexed specimens, 59.3-64.8 mm SL, Gulf of Mannar, $70 \mathrm{~m}$ depth, demersal trawl, Cat. No. GUMSMB/TTN/TELO-6/13.

Diagnosis: D1 VII, D2 I 9; A II 8; P 15; V I 5; LS 26-27; total GR 14-15 (2+11 developed). Body small covered with ctenoid scales, its depth 2.80-2.91 in SL; head 2.38-2.44 in SL, snout short, 5.49-6.08 in HL. Preopercle edge smooth; palatine teeth present, caudal fin rounded; body silvery with four or five rows of scales with brownish spots, large dark ocellus on first dorsal fin, distal edges of anal and caudal fins black (Fig. 2F).
Geographical distribution: Red Sea and southern Africa to Persian Gulf and Arabian Sea off India (Gon and Randall 2003). This species is known to have migrated from the Red Sea to the Mediterranean Sea through the Suez Canal (Eryilmaz and Dalyan 2006).

Remarks: Apogon queketti along with Apogon carinatus Cuvier, 1828 and Apogon poecilopterus Cuvier, 1828 was grouped together within the carinatus-group of the subgenus Jaydia by Gon (1996) on the basis of shared characters such as smooth preopercular and post-temporal ridges, series of spots on the body and absence of dark spots on the peritoneum. Apogon queketti differs from the latter two species in having large dark ocellus on posterior part of first dorsal fin, conspicuous parallel rows of dark brown spots on scales forming longitudinal rows on the sides and anal and caudal fins with dark distal edges. On the other hand, A. carinatus has a dark ocellus on second dorsal fin and dark spots on sides are not arranged in rows, whereas $A$. poecilopterus lacks ocellus on dorsal fin and dark spots on sides (instead, it bears large indistinct black blotches on sides). The Zoological Museum Hamburg contains specimens of this species those were collected off Kerala (ZMH 5035) and Gulf of Kutch (ZMH $5036)^{*}$. This suggests that the species observed during the present study is a new record for the east coast of India.

Apogon semiornatus Peters, 1876

Material Examined: 1 unsexed specimen: $41.0 \mathrm{~mm} \mathrm{SL}$, Gulf of Mannar, $17 \mathrm{~m}$ depth, demersal trawl, Cat. No. GUMSMB/TTN/TELO-1/02. The photograph provided (Fig. 2G) is of formalin-preserved specimen.

Diagnosis: D1 VI, D2 I 9; A II 8; P 12; V I 5; LL 24; total GR 3+12 (1+6 developed). Body slender, covered with ctenoid scales, its depth 3.20 in SL; head large, 2.55 in SL, snout short, 4.35 in HL. Body coloration (in life) translucent red, sides marked with two black stripes, first one extending from posterior border of orbit to base of pectoral fin, second one inconspicuous, extending from below soft dorsal fin to posterior caudal fin margin.

Geographical distribution: Red Sea southern Africa to Japan and Australia (Gon and Randall 2003).

Remarks: Apogon semiornatus is similar in colour pattern only to Apogon lativittatus Randall, 2001. However, it differs from the latter in having only 12 pectoral fin rays as compared to 13 in the latter (Randall 2001). This species has been reported previously from Castle Bay, Nicobar Islands (Froese and Pauly 2013). Hence, the presently reported observation of this species is a new record for the east coast of India.

\section{NEMIPTERIDAE Regan, 1913}

Scolopsis Cuvier, 1814

Scolopsis xenochroa Günther, 1872

Material examined: 1 unsexed specimen: $110.8 \mathrm{~mm} \mathrm{SL}$, trawl by-catch at Tuticorin fisheries harbour, Cat. No. GUMSMB/TTN/TELO-21/02.

Diagnosis: D X 9; A III 7; P 17; V I 5; LL 44; total GR 9. Body moderately deep, covered with ctenoid scales, its 
depth 3.21 in SL, head large, 2.92 in SL, with short snout, 3.58 in HL. Scales on top of head not reaching to level of posterior nostril; small antrorse spine present below eye; maxillary smooth along its external edge. Details of body coloration conforming to those provided by Froese and Pauly (2013) as "Upper body greyish brown, silvery white below, pearly streak from behind eye along dorsal fin base, an oblique brown-edged pearly blue bar above pectoral base, an elongate white blotch below lateral line on posterior half of body with yellowish tinge above it, snout dusky and black blotch on opercle" (Fig. 2H).

Geographical distribution: Maldives, Sri Lanka to north-eastern Australia, New Guinea, and Solomon Islands (Russell 1990).

Remarks: Scolopsis xenochroa has easily distinguishable coloration. Among the 13 species of genus Scolopsis known from Indian waters (Barman and Mishra 2009, Mishra et al. 2013), S. xenochroa is the most similar to Scolopsis ciliata (Lacepède, 1802) in possessing a small antrorse spine below eye. It differs from three congeners namely Scolopsis bilineata (Bloch, 1793), Scolopsis igcarensis Mishra, Biswas, Russell, Satpathy et Selvanayagam, 2013, and Scolopsis vosmeri (Bloch, 1792) in the lesser forward extent of the scaly area on top of head (up to the anterior nostril in the latter three species). Additionally it differs from the
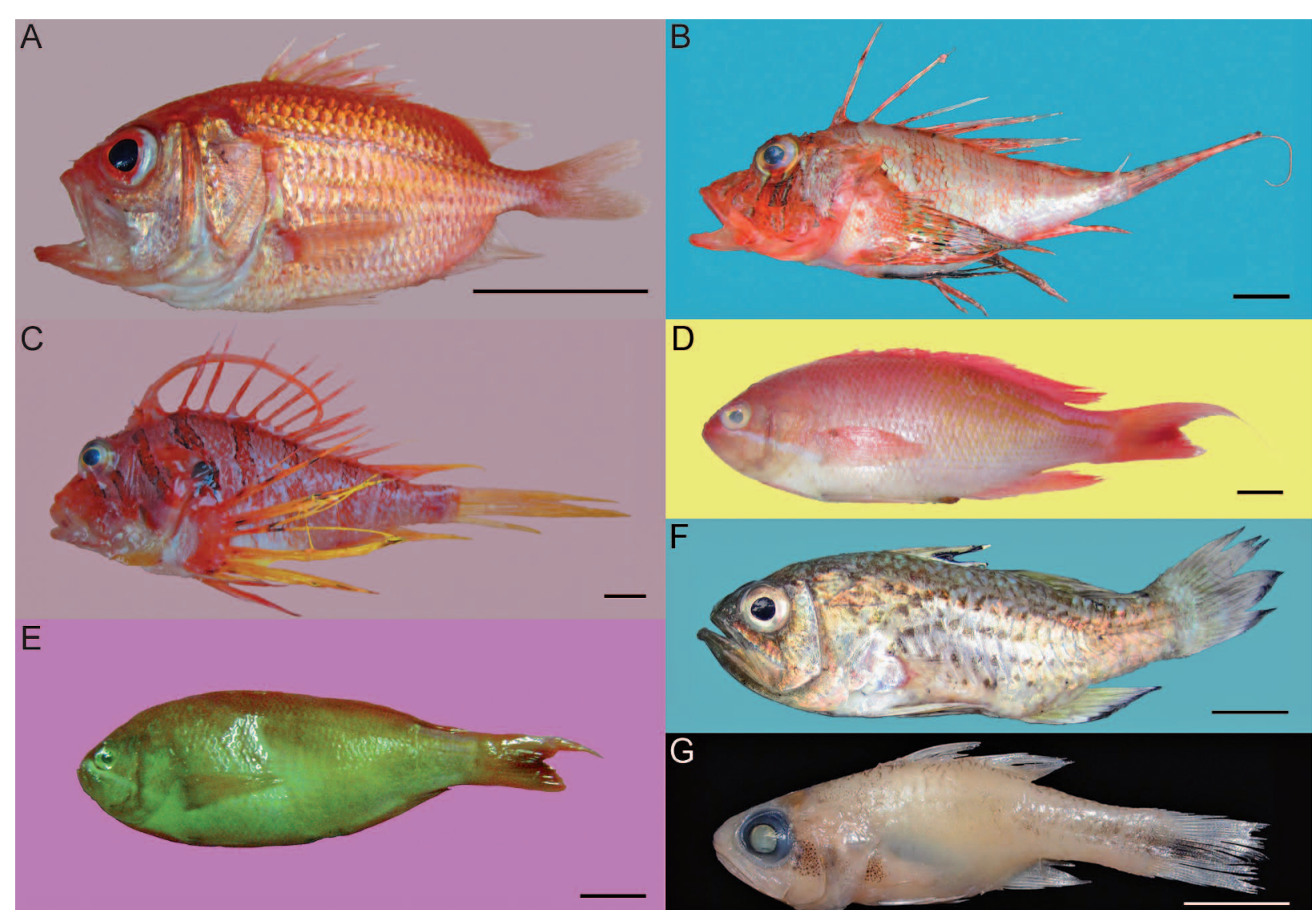

remaining eight species-Scolopsis aurata Park, 1797, Scolopsis bimaculata Rüppell, 1828, Scolopsis frenata (Cuvier, 1830), Scolopsis ghanam (Forsskål, 1775), Scolopsis lineata Quoy et Gaimard, 1824, Scolopsis margaritifera (Cuvier, 1830), Scolopsis taeniata (Cuvier, 1830), and Scolopsis taenioptera (Cuvier, 1830) - in having a small antrorse spine below the eye. A specimen of $S$. xenochroa previously collected from the Andamans is placed in the CMFRI collection (Ref. No. CMFRI-F.105/316) (Murty 1969). It was reported from Sri Lankan coast of Gulf of Mannar (Öhman et al. 1997). Hence, the presently reported observation of this species is a new record from the east coast of India.

\section{CHAETODONTIDAE Rafinesque, 1815}

Roa Jordan, 1923

Roa jayakari (Norman, 1939)

Material examined: 1 unsexed specimen: $81.4 \mathrm{~mm}$ SL, Gulf of Mannar, $106 \mathrm{~m}$ depth, demersal trawl, Cat. No. GUMSMB/TTN/TELO-7/01.

Diagnosis: D XI 21; A III 18; P 14; V I 5; LL 46; total GR 13. Body very deep, covered with large ctenoid scales, its depth 1.43 in SL, head large, 2.11 in SL, snout short, 3.47 in HL. Body coloration comprising three light brown bars with golden tinge, first band slender and extending from anterior tip of dorsal fin, along orbit; second band broadest
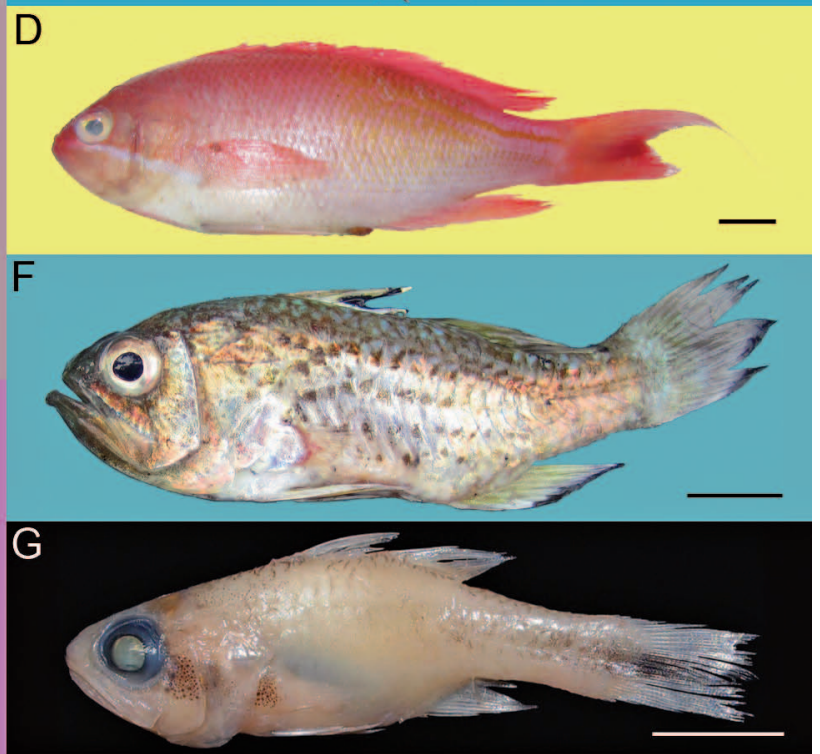

Fig. 2 A-G. Selected rare marine fishes from the Gulf of Mannar, India: Ostichthys acanthorhinus (A); Parapterois heterura (B); Ebosia falcata (C); Pseudanthias marcia male (D); Pseudanthias marcia female (E); Apogon queketti (F); Apogon semiornatus (G); Scale bars: $50 \mathrm{~mm}(\mathrm{~A}), 10 \mathrm{~mm}$ (B through G)

\footnotetext{
* Zoologisches Museum Hamburg - Collection Database. University of Hamburg - Biocenter Grindel and Zoological Museum - Section Ichthyology http://webapp5.rrz.uni-hamburg.de/fishcollection/frm_suche.php.
} 
and extending from 4th-5th dorsal fin spines down to belly; third band extending from 7th-11th dorsal fin spines and anterior dorsal rays down to soft anal fin; a conspicuous round black ocellus present on middle of soft dorsal fin; soft portion of pelvic fin black (Fig. 2I).

Geographical distribution: Red Sea, Gulf of Aden, Gulf of Oman, southern Arabian coast, and west coast of India (Burgess 1978).

Remarks: Roa jayakari differs from its only two congenersRoa australis Kuiter, 2004 and Roa excelsa (Jordan, 1921)in the shape of the black ocellus on the dorsal fin (elongated in the latter two species) (Kuiter 2004). Additionally, R. jayakari shares the character "white-edged round black ocellus on the soft portion on the dorsal fin" with Roa modesta Temminck et Schlegel, 1844 and differs from it in having straight profile of the spinous portion of dorsal fin and the lack of blackedged bars (Kuiter 2004). However, FishBase (Froese and Pauly 2013) reassigned the latter species to the genus Chaetodon due to moderately long 3rd-5th dorsal fin spines. Roa jayakari has been reported previously off the south-west coast of India (George and Dayanandan 1966). In view of the above, this species is a new record for the east coast of India, suggesting its range extension.

PENTACEROTIDAE Bleeker, 1859

Histiopterus Temminck et Schlegel, 1844

Histiopterus typus Temminck et Schlegel, 1844
Material examined: 1 unsexed specimen: $78.8 \mathrm{~mm}$ SL, Gulf of Mannar, $106 \mathrm{~m}$ depth, demersal trawl, Cat. No. GUMSMB/TTN/TELO-7/04.

Diagnosis: D IV 25; A III 8; P 17; V I 5; LL 58; total GR 21. Body short very deep, covered with minute ctenoid scales, its depth 1.63 in SL, head large, 2.15 in SL, with large snout, 2.27 in HL. Vomer toothless; profile of dorsal fin slightly rounded, third dorsal spine longer than fourth one and more robust (this character could not be confirmed due to broken tip of third spine). Body coloration light greyish, with darker blotches on body and fins (Fig. 2J).

Geographical distribution: Red Sea and southern Africa to Australia and Japan (Froese and Pauly 2013).

Remarks: Histiopterus typus is the only representative species of the genus Histiopterus. It is similar only to Evistias acutirostris (Temminck et Schlegel, 1844) in possessing fewest number (four each) of dorsal fin spines among all pentacerotids (Hardy 1983). However, it differs from the latter species in possessing a more robust third dorsal spine (Hardy 1983). This species was reported by Naomi et al. (2011) from trawl catches off Kerala. However, this is the first report of its occurrence along the east coast of India.

LABRIDAE Cuvier, 1816

Macropharyngodon Bleeker, 1862

Macropharyngodon ornatus Randall, 1978

Material examined: 1 female specimen: $98.2 \mathrm{~mm}$ SL,

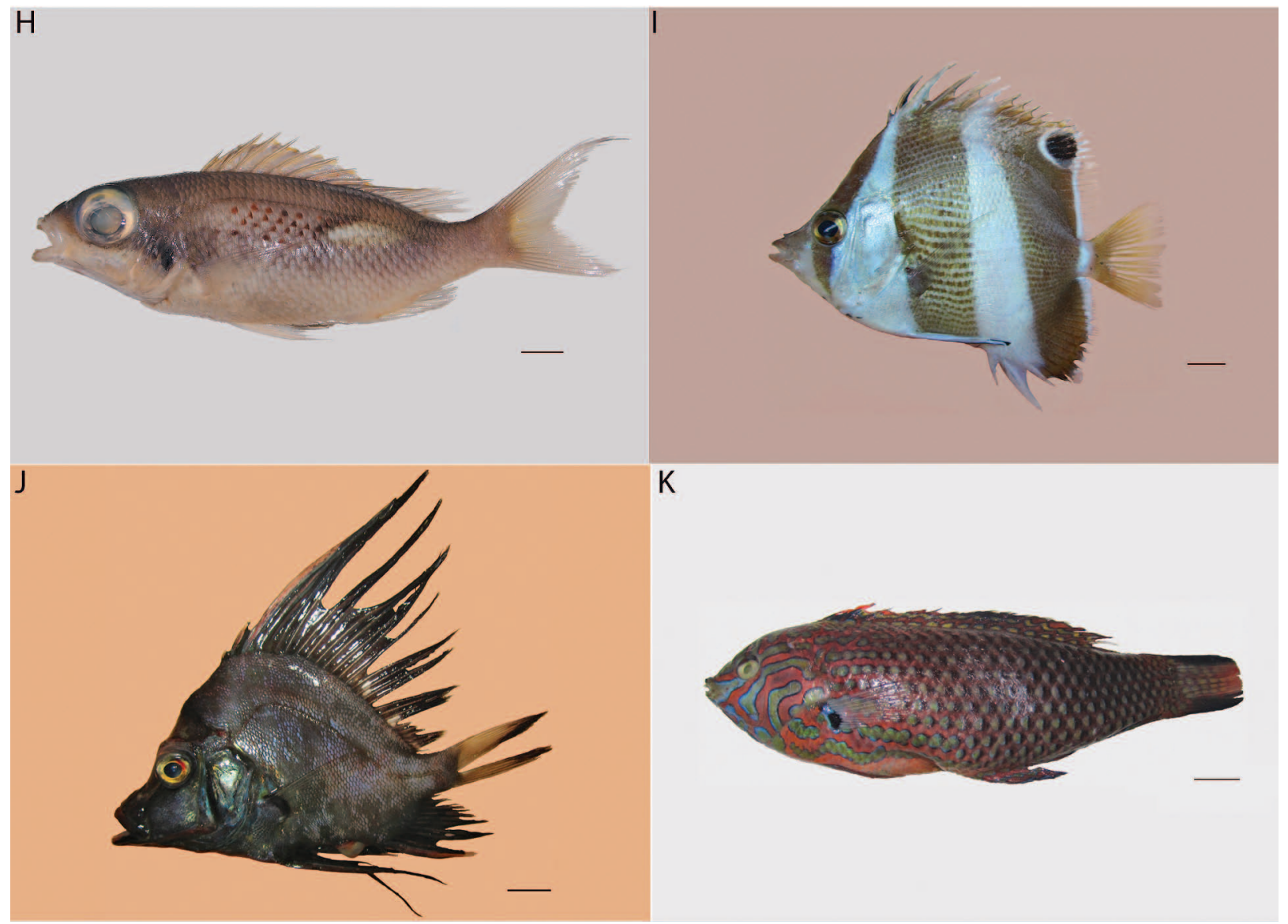

Fig. 2 H-K. Selected rare marine fishes from the Gulf of Mannar, India (continuation): Scolopsis xenochroa (H); Roa jayakari (I); Histiopterus typus (J); Macropharyngodon ornatus (K); Scale bar: $10 \mathrm{~mm}$ 
trawl by-catch at Tuticorin fisheries harbour, Cat. No. GUMSMB/TTN/TELO-5/08.

Diagnosis: D IX 11; A III 10; P 12; V I 5; LL (interrupted) 27; total GR 18. Body moderately deep, covered with ctenoid scales, its depth 3.17 in SL, head large, 3.35 in SL, with short snout, 3.45 in HL. Present specimen is female with characteristic reddish coloration in anterior half of body, shading to blackish posteriorly; each scale greenish yellow and edged with light blue and black, bands on head of similar coloration (Fig. 2K).

Geographical distribution: Sri Lanka to Western Australia and New Guinea (Randall 1978).

Remarks: Macropharyngodon ornatus is distinguished from its congeners by virtue of its characteristic coloration (Randall 1978). The only other congener known from Indian waters is Macropharyngodon meleagris (Valenciennes, 1839) (see Venkataraman et al. 2012), in which the females are whitish to light greenish with irregular black spots. This species was reported previously from Trincomalee on the eastern coast of Sri Lanka (Randall 1978). Moreover, recent paper on reef fishes from the Sri Lankan coast of Gulf of Mannar (Öhman et al. 1997) did not report this species. Therefore, the presently reported observation of this species constitutes a new record for the east coast of India.

This study was undertaken as a part of the Ballast Water Management Programme India to document the epi-faunal fish and invertebrate diversity in the Gulf of Mannar. This exercise revealed 287 taxa of benthic epi-fauna including some of the rarest fishes and invertebrates. The presently reported observation of these species in the Gulf of Mannar underlines the significance of this region as a biodiversity "hotspot". These findings enhance the current knowledge of fish assemblages in the reef ecosystems of India. Moreover, they suggest that increased mechanized fishing in the vicinity of complex reef habitats has enabled to unravel the occurrence of rare demersal fauna. Secondly, they also indicate towards lack of taxonomic expertise that hampered their identification in the past.

Existing published reports of occurrence of the aforementioned species indicate that, except Apogon semiornatus and Histiopterus typus (Indo-Western Pacific distribution), the majority of species are either distributed exclusively in the Western Indian Ocean or the Eastern Indian Ocean-Western Pacific bioregions. The occurrence of these species in the Gulf of Mannar associated with their known zoogeographical affinities suggests that the Gulf of Mannar and Palk Bay could be transitional geographical entities separating the two bioregions.

However, despite the importance of the Gulf of Mannar as a biodiversity "hotspot" and the declaration of a Biosphere Reserve, the coral habitats in this region have been extensively mined over the past five decades for construction material (Pillai 1996). Moreover, there is large scale exploitation of commercial fishes, even poaching of rare reef fishes, some of which are included in the IUCN's list of threatened species (Salin et al. 2005). Moreover, physical and physiological stresses on these reefs and their fish inhabitants were exacerbated by recent climatic perturbations. The El Niño Southern Oscillation event in 1998 caused up to $89 \%$ coral bleaching in this region (Arthur 2000). Subsequently, the tsunami in 2004 caused substantial reduction of live coral cover and sea grass vegetation (Kumarguru et al. 2005). Recent studies on the effects of increasing sea surface temperatures on coral assemblages from Gulf of Mannar have revealed extensive mortality among bleached coral recruits (Patterson Edward et al. 2008), along with predictions of phase shift from coral dominated ecosystem to an algal dominated one (Jeevamani et al. 2013). Further, release of untreated effluents and sedimentation of reefs due to altered land use patterns in the region also pose potential threats to the fragile coral reef and sea grass ecosystems in the region (Mathews and Edward 2006, Edward et al. 2012). In view of the above scenario, it is mandatory to continuously update the documentation of rare species to enable understanding of their role in ecosystem functioning, and advance conservation measures effectively.

\section{ACKNOWLEDGEMENTS}

The authors take this opportunity to express their gratitude to the Ballast Water Management Programme, India executed by National Institute of Oceanography, Dona Paula, Goa for Directorate General of Shipping, Ministry of Shipping, Government of India. Special thanks are due to Mr. Venkat Krishnamurthy, NIO for editing the illustrations.

\section{REFERENCES}

Allen G.R. 1999. Apogonidae: Cardinalfishes. Pp. 2602-2610. In: Carpenter K.E., Niem V.H. (eds.) FAO species identification guide for fishery purposes. The living marine resources of the Western Central Pacific. Volume 4: Bony fishes part 2 (Mugilidae to Carangidae). FAO, Rome.

Arthur R. 2000. Coral bleaching and mortality in three Indian reef regions during an El Niño southern oscillation event. Current Science 79 (12): 1723-1729.

Barman R.P., Mishra S.S. 2009. A pictorial guide to the fishes of the family Nemipteridae of India. Zoological Survey of India, Kolkata, India.

Burgess W.E. 1978. Butterflyfishes of the world. A monograph of the Family Chaetodontidae. TFH Publications, Neptune City, NJ. USA.

Dorairaj K. 1998. Economics and ecological diversity of marine fish resources. Pp. 129-149. In: Rajeswari M.A., Dorairaj K., Parida A. (eds.) Proceedings of the technical workshop on biodiversity of Gulf of Mannar marine biosphere reserve; 10-11 February 1998, Chennai, India. M.S. Swaminathan Research Foundation, Chennai, India.

Edward J.P.K., Mathews G., Raj K.D., Thinesh T., Patterson J., Tamelander J., Wilhelmsson D. 2012. Coral reefs of Gulf of Mannar, India - signs of resilience. 5 pp. In: Proceedings of the 12th International Coral Reef Symposium, 9-13 July 2012; Cairns, Australia.

Eryilmaz L., Dalyan C. 2006. First record of Apogon queketti Gilchrist (Osteichthyes: Apogonidae) in the Mediterranean 
Sea. Journal of Fish Biology 69 (4): 1251-1254. DOI: 10.1111/j.1095-8649.2006.01185.x

Eschmeyer W.N. (ed.) 2013. Catalog of Fishes online. http://researcharchive.calacademy.org/research/ichthyology /catalog/fishcatmain.asp

Eschmeyer W.N., Rama-Rao K.V. 1977 [published: 1978]. A new scorpionfish, Ebosia falcata (Scorpaenidae, Pteroinae), from the western Indian Ocean, with comments on the genus. Matsya 3: 64-71.

Froese R., Pauly D. (eds.) 2013. FishBase. [version 08/2013]. http://www.fishbase.org

George K.C., Dayanandan M.G. 1966. Atrophacanthus danae Fraser Brunner and Chaetodon jayakari Norman, new records of fishes from the Arabian Sea off the south-west coast of India. Journal of the Marine Biological Association of India 8 (1): 220-221.

Gon O. 1996. Revision of the cardinalfish subgenus Jaydia (Perciformes, Apogonidae, Apogon). Transactions of the Royal Society of South Africa 51 (1): 147-194. DOI: 10.1080/00359199609520605

Gon O., Randall J.E. 2003. A review of the cardinalfishes (Perciformes: Apogonidae) of the Red Sea. Smithiana Bulletin 1 (1): 1-48.

Hardy G.S. 1983. A revision of the fishes of the family Pentacerotidae (Perciformes). New Zealand Journal of Zoology 10 (2): 177-220. DOI: 10.1080/03014223.1983. 10423906

Heemstra P.C. 2001. Pentacerotidae: Armourheads. Pp. 3288-3289. In: Carpenter K.E., Niem V.H. (eds.) FAO species identification guide for fishery purposes. The living marine resources of the Western Central Pacific. Volume 5: Bony fishes part 3 (Menidae to Pomacentridae). FAO, Rome.

Heemstra P.C., Akhilesh K.V. 2012. Review of the anthiine fish genus Pseudanthias (Perciformes: Serranidae) of the western Indian Ocean, with description of a new species and a key to the species. Aqua International Journal of Ichthyology 18 (3): 121-164.

Heemstra P.C., Randall J.E. 1999. Serranidae: Groupers and seabasses (also, soapfishes, anthiines, etc.). Pp. 2442-2548. In: Carpenter K.E., Niem V.H. (eds.) FAO species identification guide for fishery purposes. The living marine resources of the Western Central Pacific. Volume 4: Bony fishes part 2 (Mugilidae to Carangidae). FAO, Rome.

Jeevamani J.J.J., Kamalakannan B., Nagendran N.A., Chandrasekaran S. 2013. Climate change induced coral bleaching and algal phase shift in reefs of the Gulf of Mannar, India. Pp. 87-94. In: Nautiyal S., Rao K.S., Kaechele H., Raju K.V., Schaldach R. (eds.) Knowledge systems of societies for adaptation and mitigation of impacts of climate change. Book series: Environmental Science and Engineering. Springer, Heidelberg, New York, Dordrecht, London. DOI: 10.1007/978-3-642-36143-2_6

Kathal P.K. 2005. Sethusamudram Ship Canal Project: oceanographic/geological and ecological impact on marine life in the Gulf of Mannar and Palk Bay, southeastern coast of India. Current Science 89 (7): 1082-1083.

Kuiter R.H. 2004. Description of a new species of butterflyfish, Roa australis, from northwestern Australia (Pisces:
Perciformes: Chaetodontidae). Records of the Australian Museum 56: 167-171. DOI: 10.3853/j.0067-1975. 56.2004 .1424

Kumarguru A.K., Jayakumar K., Jerald Wilson J., Ramakritinan C.M. 2005. Impact of the tsunami of 26 December 2004 on the coral reef environment of Gulf of Mannar and Palk Bay in the southeast coast of India. Current Science 89 (10): 1729-1741.

Mathews G., Edward J.K.P. 2006. Effect of sedimentation and pollution in the reefs of Tuticorin coast of Gulf of Mannar, southeast coast of India. Pp. 837-841. In: Suzuki Y., Nakamori T., Hidaka M., Kayanne H., Casareto B.E., Nadaoka K., Yamano H., Tsuchiya M. (eds.) Proceedings of 10th International Coral Reef Symposium; 28 June-2 July 2004, Okinawa, Japan. Japanese Coral Reef Society, Tokyo, Japan.

Matsunuma M., Jawad L.A., Motomura H. 2013. New records of a scorpionfish, Parapterois macrura (Scorpaenidae: Pteroinae), from Oman and Somalia, western Arabian Sea. Biogeography 15: 49-54.

Mishra S.S., Biswas S., Russell B.C., Satpathy K.K., Selvanayagam M. 2013. A new species of the genus Scolopsis Cuvier, 1830 (Perciformes: Nemipteridae) from southern India and Sri Lanka. Zootaxa 3609 (4): 443-449. DOI: 10.11646/zootaxa.3609.4.7

Motomura H. 2004. Morphological comparison of a poorly known scorpionfish, Parapterois macrura, with a related species, P. heterura (Scorpaenidae: Pteroinae). Zoological Studies 43 (1): 1-7.

Murty V.S. 1969. Catalogue of fishes (excluding from the Laccadives) in the reference collections of the Central Marine Fisheries Research Institute. Bulletin of the Central Marine Fisheries Research Institute 1969 (10): 1-38.

Nair R.J. 2008. Taxonomic account of Marcia's Anthias, Pseudanthias marcia Randall \& Hoover, 1993 (Serranidae: Anthiinae), a new record from India. Journal of the Marine Biological Association of India 50 (1): 98-102.

Naomi T.S., Rani Mary George, Miriam Paul Sreeram, Sanil N.K., Balachandran K., Thomas V.J., Geetha P.M. 2011. Finfish diversity in the trawl fisheries of southern Kerala. Marine Fisheries Information Service; Technical and Information Series 207: 11-21.

Nelson J.S. (ed.) 2006. Fishes of the World. Fourth Edition. John Wiley and Sons, Hoboken, NJ, USA.

Öhman M.C., Rajasuriya A., Ólafsson E. 1997. Reef fish assemblages in north-western Sri Lanka: distribution patterns and influences of fishing practices. Environmental Biology of Fishes 49 (1): 45-61. DOI: 10.1023/ A:1007309230416

Patterson Edward J.K., Mathews G., Diraviya Raj K., Tamelander J. 2008. Coral reefs of the Gulf of Mannar, southeastern India-observations on the effect of elevated SST during 2005-2008. Pp. 1286-1288. In: Proceedings of the 11th International Coral Reef Symposium, 7-11 July 2008; Ft. Lauderdale, FL, USA.

Pillai C.S.G. 1996. Coral reefs of India, their conservation and management. Pp.16-31. In: Menon N.G., Pillai C.S.G. (eds.) Marine Biodiversity, Conservation and Management. Central Marine Fisheries Research Institute, Cochin, India. 
Poss S.G. 1999. Scorpaenidae: Scorpionfishes (also, lionfishes, rockfishes, stingfishes, stonefishes, and waspfishes). Pp. 2291-2352. In: Carpenter K.E., Niem V.H. (eds.) FAO species identification guide for fishery purposes. The living marine resources of the Western Central Pacific. Volume 4: Bony fishes part 2 (Mugilidae to Carangidae). FAO, Rome.

Pyle R. 2001. Chaetodontidae: Butterflyfishes. Pp. 3224-3265. In: Carpenter K.E., Niem V.H. (eds.) FAO species identification guide for fishery purposes. The living marine resources of the Western Central Pacific. Volume 5: Bony fishes part 3 (Menidae to Pomacentridae). FAO, Rome.

Randall J.E. 1978. A revision of the Indo-Pacific labrid fish genus Macropharyngodon, with descriptions of five new species. Bulletin of Marine Science 28 (4): 742-770.

Randall J.E. 2001. Four new cardinalfishes (Perciformes: Apogonidae) from the Marquesas Islands. Pacific Science 55 (1): 47-64. DOI: 10.1353/psc.2001.0006

Randall J.E., Hoover J.P. 1993. Pseudanthias marcia, a new serranid fish from Oman. Revue francaise d'Aquariologie 20 (2): 47-52.

Randall J.E., Shimizu T., Yamakawa T. 1982. A revision of the holocentrid fish genus Ostichthys, with descriptions of four new species and a related new genus. Japanese Journal of Ichthyology 29 (1): 1-26.

Russell B.C. (ed.) 1990. FAO species catalogue. Vol. 12. Nemipterid fishes of the World. (Threadfin breams, whiptail breams, monocle breams, dwarf monocle breams and coral breams). Family Nemipteridae. An annotated and illustrated catalogue of nemipterid species known to date. FAO Fisheries Synopsis. No. 125, Volume 12. FAO, Rome.

Russell B.C. 2001. Nemipteridae: Threadfin breams (also whiptail breams, monocle breams, dwarf monocle breams, and coral breams). Pp. 3051-3089. In: Carpenter K.E., Niem V.H. (eds.) FAO species identification guide for fishery purposes. The living marine resources of the Western Central Pacific. Volume 5: Bony fishes part 3 (Menidae to Pomacentridae). FAO, Rome.
Salin K.R., Yohannan T.M., Nair C.M. 2005. Fisheries and trade of seahorses, Hippocampus spp., in southern India. Fisheries Management and Ecology 12: 269-273. DOI: 10.1111/j.1365-2400.2005.00450.x

van der Laan R., Fricke R., Eschmeyer W.N. 2013. Familygroup names in fishes. [Online version, updated 15 Nov. 2013] San Francisco (California Academy of Sciences). http://research.calacademy.org/ichthyology/catalog/family

Varghese M., Manisseri M.K., Ramamurthy N., Geetha P.M., Thomas V.J., Gandhi A. 2011. Coral reef fishes of Gulf of Mannar, S.E. of India. Fishing Chimes 31 (1): 38-40.

Venkataraman K., Jeyabaskaran R., Satyanarayana C., Raghuram K.P. 2004. Status of coral reefs in Gulf of Mannar Biosphere Reserve. Records of the Zoological Survey of India 103 (1-2): 1-15.

Venkataraman K., Rajkumar Rajan, Satyanarayana C., Raghunathan C., Venkataraman C. 2012. Marine Ecosystems and Marine Protected Areas of India. Director, Zoological Survey of India, Kolkata.

Venkataraman K., Wafar M. 2005. Coastal and marine biodiversity of India. Indian Journal of Marine Sciences 34 (1): $57-75$.

Venkataramani V.K., Jawahar P., Vaitheeswaran T., Santhanam R. 2005. Marine Ornamental fishes of Gulf of Mannar. ICAR-NATP-CGP publication, India.

Westneat M.W. 2001. Labridae: Wrasses (also, hogfishes, razorfishes, corises, and tuskfishes). Pp. 3381-3467. In: Carpenter K.E., Niem V.H. (eds.) FAO species identification guide for fishery purposes. The living marine resources of the Western Central Pacific. Volume 6: Bony fishes part 3 (Menidae to Pomacentridae). FAO, Rome.

Received: 24 September 2013

Accepted: 13 May 2014

Published electronically: 15 October 2014 